\title{
No-till broccoli farming over pearl millet: weed suppression and yield at consecutive seasons in the southern coast of Brazil
}

\author{
Cultivo de brócoli cero labranza sobre mijo perla: supresión de malezas y \\ productividad en períodos consecutivos en la costa sur de Brasil \\ Ivete Maria Grisa ${ }^{1}$; Átila Fransisco Mógor ${ }^{2 *}$; Henrique S Koehler ${ }^{2}$; \\ Viviane S Mendes ${ }^{1}$; Scheila R Da Rolt ${ }^{1}$
}

\begin{abstract}
The pearl millet is a potential feedstock for biomass production under sensitive areas to climate changes, as the southern coast of Brazil. Looking for the sustainability of small-scale vegetable farmers on that region, the aim of this study was to evaluate the effect of pearl millet as a cover crop on suppression of weeds during no-tillage cultivation of broccoli for two consecutive seasons. The experimental design was a randomized block with four treatments and four replications in split-plot design over time. Soil covering with whole millet; milled millet; spontaneous weeds (fallow) and conventional planting were tested; by they could causes changes in the community of weeds, either in the occurrence of weed species and in the accumulation of their biomass with influence on the yield of broccoli. The weed species density average over the two seasons, from higher to lower, followed respectively: Cyperus rotundus, Eleusine indica, Galinsoga quadriradiata, Cynodon dactylon, Commelina erecta and Amaranthus lividus. It was verified that soil covering with pear millet has altered weeds population dynamic and their biomass, being efficient in suppress the emergence of weeds. At the second season, the soil covered with whole pearl millet increased the yield of broccoli in comparison to the conventional system, being a sustainable technique for family farmers.
\end{abstract}

Keywords: Brassica oleracea var. italica, Pennisetum glaucum, soil covering, weeds.

\section{RESUMEN}

El mijo perla es una especie potencial para la producción de biomasa en áreas sensibles a los cambios climáticos, como la costa sur de Brasil. Buscando la sostenibilidad de los pequeños productores de hortalizas en esa región, el objetivo de este estudio fue evaluar el efecto del mijo perla como cultivo de cobertura en la supresión de las malas hierbas durante el cultivo de brócoli cero labranza durante dos temporadas consecutivas. El diseño experimental fue un bloque aleatorio con cuatro tratamientos y cuatro repeticiones en el diseño de parcelas divididas a lo largo del tiempo. Suelo cubierto con mijo entero; mijo aplastado; malezas espontáneas (barbecho) y la siembra convencional se ensayaron para comprobar si podrían causar cambios en la comunidad de malezas, ya sea en la presencia de especies de malezas y en la acumulación de su biomasa con influencia en el rendimiento del brócoli. La densidad promedio de las especies de malezas durante las dos estaciones, siguió respectivamente: Cyperus rotundus, Eleusine indica, Galinsoga quadriradiata, Cynodon dactylon, Commelina erecta y Amaranthus lividus. Se verificó que la cobertura del suelo con mijo perla ha alterado la dinámica poblacional de las malezas y su biomasa, siendo eficaz para limitar la aparición de malezas. En la segunda temporada, el suelo cubierto con mijo perla entero aumentó el rendimiento del brócoli en comparación con el sistema convencional, siendo una técnica sostenible para los agricultores familiares.

Palabras clave: Brassica oleracea var. italica, Pennisetum glaucum, cubierta del suelo, malas hierbas.

\section{Introduction}

Most of the small-scale vegetable farmers have limitations in the use of high technology, which, combined with the high cost and scarcity of labor, makes the soil covering crops essential in the management of weeds on farming (Melo et al., 2010).

Interferences caused by weeds may reduce yield as the costs of production are increased by the weeds control, while the presence of biomass

1 Instituto Federal Catarinense. Sombrio-SC, Brasil.

2 Departamento de Fitotecnia e Fitossanitarismo, Setor de Ciências Agrárias, Universidade Federal do Paraná. Curitiba-PR, Brasil.

* Corresponding author: atila.mogor@ufpr.br

Fecha de Recepción: 10 Enero, 2019.

Fecha de Aceptación: 25 Febrero, 2019. 
covering the soil will form a layer that limits the passage of light by inhibiting seed germination, impairing the initial development of the weeds (Farooq et al. 2011).

In no-tillage farming, the biomass produced by the cover crops protects the soil from the effects of solar rays and raindrops, reduces water loses, increases nutrient cycling besides being an alternative to weed control, reducing or even suppressing the population of spontaneous plants (Chauhan et al. 2012).

Among the species reported as cover crops, pearl millet (Pennisetum glaucum (L.) R.Br.) has showed efficiency on suppressing weeds (Meschede et al. 2007), and has been tested in Brazil for no-tillage vegetable production (Hirata et al. 2014). Pearl millet belongs to the Poaceae family presenting high rusticity, been a potential feedstock for biomass production under sensitive areas to climate changes (Fabbrin et al. 2015), as the Brazil's Southern Coast agriculture areas (Mendelsohn, 2008).

Therefore, aiming to support the small-scale vegetable farmers of the coast of Santa Catarina State - Southern Brazil, the objective of this work was to determine whether the biomass of whole or milled pearl millet, and the residue of spontaneous plants (fallow), could causes changes in the community of weeds, either in the occurrence of weed species and in the accumulation of their biomass and their influence on the yield of broccoli in no -tillage farming system by two consecutive seasons.

\section{Materials and methods}

This work was carried out for two consecutive seasons (2013/14 and 2014/15) in the vegetables production area at Instituto Federal Catarinense Campus Santa Rosa do Sul, located on the coast of Santa Catarina State, Southern Brazil, at the geographic coordinates $29^{\circ} 08^{\prime} 05^{\prime \prime} \mathrm{S}, 49^{\circ} 42^{\prime} 00^{\prime \prime} \mathrm{W}$, at $12 \mathrm{~m}$ above sea level. The climate, according to Köppen's classification is Cfa, and is characterized as humid temperate, with hot summer and annual average rainfall ranging from 1500 to $1800 \mathrm{~mm}$. The soil chemical analysis identified the following values: $\mathrm{pH}\left(\mathrm{H}_{2} \mathrm{O}\right)$ : 6.3; $\mathrm{P}$ (Mehlich-1): >100 and $\mathrm{K}$ : $292.3\left(\mathrm{mg} / \mathrm{dm}^{3}\right)$; Al: 0.0; Ca: 7.8; Mg: 3.3 and CEC: $14.5\left(\mathrm{cmol}_{\mathrm{c}} / \mathrm{dm}^{3}\right)$; soil base saturation: $82.2 \%$, being suitable for the broccoli cultivation. At the second season the soil fertilization was carried out based on recommendations for broccoli cultivation.
The experimental design was a randomized complete block with four treatments and four replications, with split -plot over time (two successive seasons). The treatments were: soil covered with whole pearl millet (Pennisetum glaucum L.) (MI); ground milled pearl millet (GM); spontaneous plants (fallow) (SP) and conventional planting without soil covering $(\mathrm{CP})$.

In November 2013 and 2014, pearl millet (BRS 1501) was sown manually in rows spaced by $20 \mathrm{~cm}$, maintaining a population of 250.000 plants per hectare. The cover treatment of spontaneous plants (SP) consisted of the endemic species that emerged from propagules and seeds over each plot ( $1 \mathrm{~m}$ wide and $8 \mathrm{~m}$ long). In the conventional system, the soil was prepared using a rotating hoe one week before broccoli seedlings transplanting.

Soil covering biomass management was made by hand and performed when the pearl millet plants were at the onset of the flowering state. At the MI and SP, the plants were distributed uniformly over the plots, and at GM was used a crusher keeping pieces of $5 \pm 1 \mathrm{~cm}$, evenly distributed over the plots.

The Broccoli (Salinas F1 Topseed ${ }^{\circledR}$ ) plants were established at a spacing of $0.7 \times 0.5 \mathrm{~m}$. For yield measurement, eight plants by each plot were collected at 90 days after transplanting, showing complete expansion of inflorescences.

In order to quantify the fresh matter produced by pearl millet and by SP, a square with an inner area of $0.25 \mathrm{~m}^{2}$ was used in two random samples in each plot. Weed density were evaluated in the same way for all treatments at 15, 30, 45 and 60 days after Broccoli transplanting (DAT). The weeds were cut close to the soil for quantification, identification and determination of fresh and dry masses, estimated and expressed in $\mathrm{g} \mathrm{m}^{-2}$. Dry mass was determined by oven at $65{ }^{\circ} \mathrm{C}$ until constant weight was obtained. After each collection, all remaining weeds on plots were taken.

The data were submitted to homogeneity tests and ANOVA, compared by Tukey at $\mathrm{p}<0.05$ using software Assistat 7.7 beta.

\section{Results and discussion}

At the first season, pearl millet dry matter yield was of $23.5 \mathrm{t} \mathrm{ha}^{-1}$ (Table 1), higher than the Brazilian pearl millet average yield as a cover crop of 11,2t ha ${ }^{-1}$ (Bassegio et al., 2015). This high biomass production is related to the high soil fertility 
at plots (soil base saturation: 82.2\%). However, at the second season the pearl millet dry matter yield has dropped to $8.8 \mathrm{tha}^{-1}$. The reduction was caused by heavy rains and strong winds that affected the pearl millet, while weeds were less affected by the environment, producing $4.9 \mathrm{tha}^{-1}$ of dry matter at the first season and 3.9 $\mathrm{tha}^{-1}$ at the second on SP, were spontaneous plants was used for soil covering (fallow) (Table 1). This indicates that the presence of weeds will be increasingly challenging for the production of small-scale vegetables in the face of climate change.

On the other hand, the effect of soil covering treatments was observed by the reduction of total dry matter of weeds in both seasons (Table 1), mainly at soil covered with whole pearl millet (MI) and at ground milled pearl millet (GM) than the soil covering by SP.

At the second season, the suppressive effect of the soil covers was more evident, reducing weeds density (table 2) and biomass (Table 1), even at MI and GM despite the reduction of pearl millet biomass related to climate, indicating a long term effect of no-tillage on weeds dynamic, as reported by Alarcón et al. (2018) studding the effect of no tillage on weed community diversity and crop yield at consecutive years.

The SP was the any less efficient in both seasons, showing highest weeds dry matter accumulation even over than CP (Table 2). This is attributable to the lower biomass production of SP for soil covering (Table 1), and also to some species of weeds seeds spreading and propagules multiplication during fallow (Chauhan et al., 2012).

The weed species density average over the two seasons, from higher to lower, followed respectively: Cyperus rotundus, Eleusine indica, Galinsoga quadriradiata, Cynodon dactylon, Commelina erecta and Amaranthus lividus (Table 2).

The $C$. rotundus presented highest density among weed species, showing at first and second seasons (Table 2). Trichard et al. (2013) in a study with weed community identification in soils under no-till, proved that over the time there is an increase in semi-perennial plants, as well as in the present work in relation to $C$. rotundus. Even so, the covering with MI and PM had a higher control of $C$. rotundus when compared to the $\mathrm{SP}$ and $\mathrm{CP}$ at both seasons (Table 2).

At the first season, the lowest densities of E. indica, C. dactylon and A. lividus were observed
Table 1. Mean values of dry matter of cover plants (DM) and total dry matter of weeds (TDM) on no-till broccoli cultivation by two consecutive seasons (2013/14-2014/15) at southern coast of Brazil.

\begin{tabular}{cccrr}
\hline \multirow{2}{*}{$\begin{array}{c}\text { Seasons } \\
\text { Treatments }\end{array}$} & \multicolumn{1}{c}{ First } & Second & First & Second \\
\cline { 2 - 5 } & \multicolumn{5}{c}{ DM } \\
\cline { 2 - 5 } $\mathrm{kg} \mathrm{ha}^{-1}$ \\
\hline MI & $23.500 \mathrm{aA}$ & $8.800 \mathrm{aB}$ & $409.5 \mathrm{cA}$ & $102.0 \mathrm{cB}$ \\
GM & $23.500 \mathrm{aA}$ & $8.800 \mathrm{aB}$ & $738.8 \mathrm{bA}$ & $69.7 \mathrm{cB}$ \\
SP & $4.900 \mathrm{bA}$ & $3.900 \mathrm{bB}$ & $3958.9 \mathrm{aA}$ & $730.0 \mathrm{aB}$ \\
$\mathrm{CP}$ & $0.0 \mathrm{c}$ & $0.0 \mathrm{c}$ & $849.4 \mathrm{bA}$ & $418.5 \mathrm{bB}$ \\
\hline $\mathrm{CV}(\%)$ & 10.07 & 5.81 & 8.1 & 8.1 \\
\hline
\end{tabular}

Whole pearl millet (MI), ground milled pearl millet (GM), spontaneous plants (fallow) (SP), conventional planting without soil covering $(\mathrm{CP})$. Means followed by the same lower-case letter in the column and in the row do not differ from each other by the test of Tukey at $\mathrm{p}<0.05$ of probability.

in MI when compared to CP. At the second season, the density reduction was observed for $C$. dactylon and A. lividus (Table 2).

Unlike the other species, Galinsoga quadriradiata presented higher density at MI in the both seasons, as also observed by Carmona (1992), reporting that some weed species may present a greater emergency intensity in the no-tillage system than in the conventional one. According Damalas (2008), G. quadriradiata characteristi CP such as lack of seed dormancy, rapid growth and development, early flowering, many generations per growing season and the production of a large number of seeds in a wide range of environmental circumstances, allow the rapid and easy distribution of grass in large populations.

The results of the means of dry matter production of weeds showed interaction between soil covers by seasons, indicating that the effects are not independent (Table 3).

The less efficient soil covering was SP in all assessed times (15, 30, 45 and 60 DAT of broccoli). As this treatment was composed of species of plants that appeared spontaneously in the plots and some of them were of short cycle, they ended up contributing in the deposition of seeds that germinated and later were evaluated as weeds.

Vidal and Trezzi (2004) had observed reductions of $41 \%$ in infestation and $74 \%$ in total dry matter of weeds biomass comparing the notillage areas covered with sorghum and pearl millet 
Table 2. Density of species and total density of weeds (plants $\mathrm{m}^{-2}$ ) at 15, 30, 45 and 60 days after broccoli transplanting (DAT) on no-till broccoli cultivation by two consecutive seasons (2013/14-2014/15) at southern coast of Brazil.

\begin{tabular}{|c|c|c|c|c|c|c|c|c|c|c|c|c|c|c|c|c|c|}
\hline \multirow{2}{*}{ DAT } & & \multicolumn{4}{|c|}{ MI } & \multicolumn{4}{|c|}{ GM } & \multicolumn{4}{|c|}{ SP } & \multicolumn{4}{|c|}{$\mathrm{CP}$} \\
\hline & & 15 & 30 & 45 & 60 & 15 & 30 & 45 & 60 & 15 & 30 & 45 & 60 & 15 & 30 & 45 & 60 \\
\hline \multicolumn{6}{|l|}{ Weed species } & \multicolumn{12}{|c|}{ Density of weed species (plants $\mathrm{m}^{-2}$ ) at first season } \\
\hline \multicolumn{2}{|l|}{ C. rotundus } & 6 & 40 & 40 & 6 & 2 & 28 & 4 & 6 & 212 & 184 & 134 & 60 & 60 & 106 & 44 & 34 \\
\hline \multicolumn{2}{|l|}{ E. indica } & 0 & 6 & 0 & 0 & 132 & 0 & 24 & 0 & 200 & 20 & 24 & 0 & 52 & 10 & 0 & 0 \\
\hline \multicolumn{2}{|l|}{ C. erecta } & 0 & 28 & 10 & 10 & 4 & 16 & 18 & 12 & 18 & 24 & 0 & 2 & 8 & 12 & 4 & 2 \\
\hline \multicolumn{2}{|l|}{ C. dactylon } & 0 & 18 & 18 & 0 & 4 & 8 & 8 & 0 & 26 & 22 & 22 & 4 & 22 & 18 & 18 & 10 \\
\hline \multicolumn{2}{|l|}{ A. lividus } & 0 & 4 & 2 & 0 & 0 & 0 & 16 & 2 & 24 & 18 & 14 & 4 & 0 & 10 & 8 & 0 \\
\hline \multicolumn{2}{|l|}{ G. quadriradiata } & 0 & 146 & 10 & 10 & 0 & 46 & 32 & 8 & 0 & 20 & 24 & 14 & 20 & 24 & 20 & 12 \\
\hline \multicolumn{18}{|c|}{ Density of weed species (plants $\mathrm{m}^{-2}$ ) at second season } \\
\hline \multicolumn{2}{|l|}{ C. rotundus } & 0 & 14 & 20 & 0 & 22 & 4 & 68 & 0 & 430 & 340 & 176 & 84 & 324 & 198 & 116 & 12 \\
\hline \multicolumn{2}{|l|}{ E. indica } & 72 & 2 & 12 & 4 & 28 & 4 & 4 & 12 & 60 & 4 & 56 & 4 & 0 & 18 & 6 & 0 \\
\hline \multicolumn{2}{|l|}{ C. erecta } & 12 & 4 & 0 & 0 & 12 & 18 & 0 & 0 & 22 & 2 & 2 & 10 & 6 & 0 & 0 & 0 \\
\hline \multicolumn{2}{|l|}{ C. dactylon } & 0 & 0 & 0 & 0 & 20 & 0 & 0 & 0 & 44 & 10 & 0 & 22 & 0 & 2 & 0 & 0 \\
\hline \multirow{2}{*}{\multicolumn{2}{|c|}{$\begin{array}{l}\text { A. lividus } \\
\text { G. quadriradiata }\end{array}$}} & 8 & 2 & 0 & 2 & 0 & 2 & 4 & 4 & 0 & 6 & 14 & 4 & 0 & 42 & 4 & 2 \\
\hline & & 0 & 14 & 62 & 28 & 0 & 6 & 18 & 18 & 0 & 4 & 2 & 36 & 4 & 14 & 8 & 28 \\
\hline \multicolumn{18}{|c|}{ Density means of all weed species (plants $\mathrm{m}^{-2}$ ) } \\
\hline \multirow{2}{*}{ Total } & $1^{0}$ Season & & \multicolumn{3}{|c|}{$146,5 \mathrm{cA}$} & \multicolumn{4}{|c|}{$150,5 \mathrm{cA}$} & \multicolumn{4}{|c|}{$445,0 \mathrm{aA}$} & \multicolumn{4}{|c|}{$271,0 \mathrm{bA}$} \\
\hline & $2^{0}$ Season & & \multicolumn{3}{|c|}{$91,7 \mathrm{cB}$} & \multicolumn{4}{|c|}{$97,5 \mathrm{cB}$} & \multicolumn{4}{|c|}{$272,0 \mathrm{aB}$} & \multicolumn{4}{|c|}{$145,5 \mathrm{bB}$} \\
\hline
\end{tabular}

Whole pearl millet (MI), ground milled pearl millet (GM), spontaneous plants (fallow) (SP), conventional planting without soil covering (CP). Means followed by the same lower case letter in the column and upper case in the line do not differ statistically from each other by the Tukey test at $\mathrm{p}<0.05$ of probability.

Table 3. Means of dry matter $\left(\mathrm{g} \mathrm{m}^{-2}\right)$ of the weeds at $15,30,45$ and 60 days after broccoli transplanting (DAT) on no-till broccoli cultivation by two consecutive seasons (2013/14-2014/15) at southern coast of Brazil.

\begin{tabular}{crrcrr}
\hline First season DAT & \multicolumn{1}{c}{15} & 30 & 45 & 60 & Total \\
\hline MI & $1,0 \mathrm{cC}$ & $23,0 \mathrm{bA}$ & $11,6 \mathrm{cB}$ & $5,3 \mathrm{bC}$ & 40,9 \\
GM & $38,8 \mathrm{bA}$ & $25,5 \mathrm{bB}$ & $2,8 \mathrm{dC}$ & $6,7 \mathrm{bC}$ & 73,8 \\
SP & $267,5 \mathrm{aA}$ & $77,4 \mathrm{aB}$ & $34,4 \mathrm{aC}$ & $16,5 \mathrm{aD}$ & 395,9 \\
CP & $40,2 \mathrm{bA}$ & $14,1 \mathrm{cC}$ & $21,2 \mathrm{bB}$ & $16,9 \mathrm{aBC}$ & 92,4 \\
\hline \multicolumn{7}{c}{$\mathrm{CV} \% 7,5$} & & \\
\hline Second season DAT & 15 & 30 & 45 & 60 & Total \\
\hline MI & $7,3 \mathrm{cA}$ & $1,5 \mathrm{bB}$ & $1,3 \mathrm{cB}$ & $0,1 \mathrm{bB}$ & 10,2 \\
GM & $3,0 \mathrm{dA}$ & $0,6 \mathrm{bB}$ & $2,2 \mathrm{bcAB}$ & $1,1 \mathrm{bB}$ & 6,9 \\
SP & $37,9 \mathrm{aA}$ & $22,1 \mathrm{aB}$ & $7,1 \mathrm{aC}$ & $5,8 \mathrm{aC}$ & 72,9 \\
CP & $10,7 \mathrm{bB}$ & $21,9 \mathrm{aA}$ & $3,8 \mathrm{bC}$ & $5,4 \mathrm{aC}$ & 41,8 \\
\hline \multicolumn{7}{c}{$\mathrm{CV} \% 12,2$} & &
\end{tabular}

Whole pearl millet (MI), ground milled pearl millet (GM), spontaneous plants (fallow) (SP), conventional planting without soil covering $(\mathrm{CP})$. Means followed by the same lower case letter in the column and upper case in the line do not differ statistically from each other by the Tukey test at $\mathrm{p}<0.05$ of probability. 
in relation to the uncovered control. The MI at first season was more efficient for reducing the dry matter of weeds at 15 DAT indicating better weeds suppression at Broccoli early growth stage, being this the highest competition period among crops and weeds (Farooq et al., 2011). However, at 45 and 60 DAT, the results were similar to GM (Table 3).

The dry matter of the weeds decreases over time $(15,30,45,60$ DAT) in each seasons. This can be justified by increase in shading caused by growth of broccoli plants.

No statistically interactions among seasons or differences on broccoli yield at the first season were found (Table 4), showing that none of the soil covers used in this study influenced positively or negatively the Broccoli production at that period. This result meets those found by Nespoli et al. (2013), who concluded that under different no-tillage soils, broccoli yield did not change when compared to conventional tillage. On the other hand, at second season, it was observed that the yield was higher at MI $\left(10.18 \mathrm{t} \mathrm{ha}^{-1}\right)$ when compared to the conventional system $\left(8.90 \mathrm{t} \mathrm{ha}^{-1}\right)$ (Table 4), indicating that the no-till soil covering with whole pearl millet biomass can improve yield over the time. The average yield on both seasons was similar to that obtained by Melo et al (2010) also at no-till farming.

The results indicated that no-till broccoli farming with soil covered by pearl millet can reduce the weeds density and biomass, mainly at soil covered with whole pearl millet, which was efficient for weeds suppression at Broccoli early
Table 4. Total estimated broccoli yield $\left(\mathrm{kg} \mathrm{ha}^{-1}\right)$ on no-till broccoli cultivation by two consecutive seasons (2013/14-2014/15) at southern coast of Brazil.

\begin{tabular}{ccc}
\hline \multirow{2}{*}{ Treatments } & \multicolumn{2}{c}{ Yield $\left(\mathrm{kg} \mathrm{ha}^{-1}\right)$} \\
\cline { 2 - 3 } & First season & Second season \\
\hline MI & $11.017,5 \mathrm{a}$ & $10.186,7 \mathrm{a}$ \\
GM & $11.243,8 \mathrm{a}$ & $10.166,2 \mathrm{ab}$ \\
SP & $10.718,7 \mathrm{a}$ & $9.710,4 \mathrm{ab}$ \\
CP & $11.442,6 \mathrm{a}$ & $8.905,5 \mathrm{~b}$ \\
\hline CV\% & 9,23 & 5,91 \\
\hline
\end{tabular}

Whole pearl millet (MI), ground milled pearl millet (GM), spontaneous plants (fallow) (SP), conventional planting without soil covering (CP). Means followed by the same lower case letter in the column do not differ statistically from each other by the Tukey test at $\mathrm{p}<0.05$ of probability.

growth stage, improving yield over the time despite of unfavorable environmental circumstances. The pearl millet as a biomass producer under sensitive areas to climate changes (Fabbrin et al. 2015) is an efficient alternative for soil covering at Brazil's Southern Coast agriculture areas.

\section{Conclusions}

The soil covering with pear millet was efficient in suppress the emergence of weeds on no-till broccoli farming at two consecutive seasons. At the second season, the soil covered with whole pearl millet increased the yield of broccoli in comparison to the conventional system, being a sustainable technique for family farmers.

\section{Literature cited}

Alarcón, R.; E. Hernández-Plaza, L. Navarrete, M.J. Sánchez, A. Escudero, J.L. Hernanz, V. Sánchez-Giron and A.M. Sánchez.

2018. Effects of no-tillage and non-inversion tillage on weed community diversity and crop yield over nine years in a Mediterranean cereal-legume cropland. Soil \& Tillage Research, 179: 54-62.

Bassegio, D.; R.F. Santos, D. Secco, I. Werncke and M.V.M. Sarto. 2015. Cover crops and straw management on yield components of crambe. Bioscience Journal, 31: 1396-1403.

Carmona, $\mathrm{R}$

1992. Problemática e manejo de bancos de sementes de invasoras em solos agrícolas. Planta Daninha, 10: 5-16.

Chauhan, B.S.; R.G. Singh and G. Mahajan.

2012. Ecology and management of weeds under conservation agriculture: A review. Crop Protection, 38: 57-65.
Damalas, C.A.

2008. Distribution, biology, and agricultural importance of Galinsoga parviflora (Asteraceae). Weed Biology and Management, 8: 147-153.

Fabbrin, E.G.; Y. Gogorcena, A.F. Mógor and I. Garmendia. 2015. Pearl millet growth and biochemical alterations determined by mycorrhizal inoculation, water availability and atmospheric $\mathrm{CO}_{2}$ concentration. Crop \& Pasture Scienc, 66: 831-840.

Farooq, M.; K.C. Flower, K. Jabran, A. Wahid and K.H.M. Siddique.

2011. Crop yield and weed management in rainfed conservation agriculture. Soil \& Tillage Research, 117: 172-183.

Hirata, A.C.P.; E.K. Hirata, E.C. Guimarães, A.B. Rós and P.A. Monquero.

2014. No-tillage of crisphead lettuce on cover crops desiccated or mowed. Bragantia, 73: 178-183. 
Melo, R.A.C.; N.R. Madeira and J.R. Peixoto.

2010. Cultivo de brócolos de inflorescência única no verão em plantio direto. Horticultura Brasileira, 28: 23-28.

Mendelsohn, R.

2008. The impact of climate change on agriculture in developing countries. Journal of Natural Resources Policy Research, 1 (1): 5-19.

Meschede, D.K.; A.B. Ferreira and C.C. Ribeiro Jr. 2007. Evaluation of weed suppression using different crop covers under Brazilian cerrado soil conditions. Planta Daninha, 25: 465-471.
Nespoli, A.; J.N. Neves, S. Seabra Jr, E.M. Arantes and M.C.M. Nunes.

2013. Cultivo de brócolis de inflorescência única sob diferentes coberturas de solo. Enciclopédia Biosfera, 9: 916-925.

Trichard, A.; Alignier, A.; Chauvel, B.; Petit, S.

2013. Identification of weed community traits response to conservation agriculture. Agriculture, Ecosystems and Environment, 179: 179-186.

Vidal, R.A.; Trezzi, M.M.

2004. Potencial da utilização de coberturas vegetais de sorgo e milheto na supressão de plantas daninhas em condição de campo: I-plantas em desenvolvimento vegetativo. Planta Daninha, 22: 217-233. 